\title{
LIMK1 wt Allele
}

National Cancer Institute

\section{Source}

National Cancer Institute. LIMK1 wt Allele. NCI Thesaurus. Code C51212.

Human LIMK1 wild-type allele is located in the vicinity of $7 q 11.23$ and is approximately 39 $\mathrm{kb}$ in length. This allele, which encodes LIM domain kinase 1 protein, plays a role in stabilization of the actin cytoskeleton via inactivation of the actin binding/depolymerizing factor cofilin. Hemizygosity of the LIMK1 gene is associated with Williams syndrome. 